\title{
1 Sensitive one-step isothermal detection of pathogen-derived RNAs
}

3 Chang Ha Woo ${ }^{1,3}$, Sungho Jang ${ }^{2,3 \dagger}$, Giyoung Shin ${ }^{1}$, Gyoo Yeol Jung ${ }^{1,2 *}$, and Jeong Wook

$4 \quad$ Lee $^{1,2^{*}}$

5

$6 \quad{ }^{1}$ School of Interdisciplinary Bioscience and Bioengineering, Pohang University of Science

7 and Technology, 77 Cheongam-ro, Nam-gu, Pohang, Gyeongbuk 37673, Korea

$8 \quad{ }^{2}$ Department of Chemical Engineering, Pohang University of Science and Technology, 77

9 Cheongam-ro, Nam-gu, Pohang, Gyeongbuk 37673, Korea

$10 \quad{ }^{3}$ These authors contributed equally to this work

11 'Present address: Department of Biomedical Engineering and Biological Design Center,

12 Boston University, Boston, MA 02215, USA.

13 *Correspondence to Jeong Wook Lee (jeongwook@postech.ac.kr) and Gyoo Yeol Jung

14 (gyjung@postech.ac.kr) 
medRxiv preprint doi: https://doi.org/10.1101/2020.03.05.20031971; this version posted March 12, 2020. The copyright holder for this preprint (which was not certified by peer review) is the author/funder, who has granted medRxiv a license to display the preprint in All rights reserved. No reuse allowed without permission.

\section{Abstract}

17 The recent outbreaks of Ebola, Zika, MERS, and SARS-CoV-2 (2019-nCoV) require fast,

18 simple, and sensitive onsite nucleic acid diagnostics that can be developed rapidly to prevent

19 the spread of diseases. We have developed a SENsitive Splint-based one-step isothermal

20 RNA detection (SENSR) method for rapid and straightforward onsite detection of pathogen

21 RNAs with high sensitivity and specificity. SENSR consists of two simple enzymatic

22 reactions: a ligation reaction by SplintR ligase and subsequent transcription by T7 RNA

23 polymerase. The resulting transcript forms an RNA aptamer that induces fluorescence. Here,

24 we demonstrate that SENSR is an effective and highly sensitive method for the detection of

25 the current epidemic pathogen, severe acute respiratory syndrome-related coronavirus 2

26 (SARS-CoV-2). We also show that the platform can be extended to the detection of five other

27 pathogens. Overall, SENSR is a molecular diagnostic method that can be developed rapidly

28 for onsite uses requiring high sensitivity, specificity, and short assaying times. 
medRxiv preprint doi: https://doi.org/10.1101/2020.03.05.20031971; this version posted March 12,2020 . The copyright holder for this preprint (which was not certified by peer review) is the author/funder, who has granted medRxiv a license to display the preprint in All rights reserved. No reuse allowed without permission.

\section{Introduction}

30 Increasing global trade and travel are considered the cause of frequent emergence and rapid dissemination of infectious diseases around the world. Some life-threatening infectious diseases often have signs and symptoms similar to cold or flu-like syndromes. Early diagnosis is therefore essential to identify the diseases and provide the correct treatment. Immediate and onsite diagnostic decisions also help to prevent the spread of epidemic and pandemic infectious diseases ${ }^{1-3}$. In order to rapidly diagnose infectious diseases, a nucleic acid-based diagnosis has emerged as an alternative to the conventional culture-based, or immunoassaybased, approaches due to their rapidity or specificity ${ }^{4-6}$.

To increase sensitivity, current nucleic acid detection methods generally involve a target amplification step prior to the detection step. The conventional amplification method is based on PCR, which requires a thermocycler for delicate temperature modulation. As an alternative to the thermal cycling-based amplification, isothermal amplification methods are available, which rely primarily on a strand-displacing polymerase or T7 RNA polymerase at a constant temperature ${ }^{7}$. However, the complex composition of the isothermal amplification mixtures often renders these approaches incompatible with detection methods and whole diagnosis generally becomes a multi-step process $^{8-11}$. The diagnostic regimen with multi-step procedures requires additional time, instruments, and reagents, as well as skilled personnel to perform the diagnostic procedure. This aspect limits the broad applicability of nucleic acid diagnostics, especially in situations where rapid and simple detection is required. primarily depends on ligation of two separate probes that hybridize to adjacent sites of the

51 target sequence ${ }^{12}$. Because of their specificity, the ligation-dependent methods are used for detection of markers of genetic disorders ${ }^{13,14}$ and pathogens ${ }^{15,16}$, typically combined with 
medRxiv preprint doi: https://doi.org/10.1101/2020.03.05.20031971; this version posted March 12,2020 . The copyright holder for this preprint (which was not certified by peer review) is the author/funder, who has granted medRxiv a license to display the preprint in All rights reserved. No reuse allowed without permission.

54 efficiently ligate two DNA probes using a target single-stranded RNA as a splint, enabling the sequence-specific detection of RNA molecule ${ }^{17,18}$. Because the reaction components of the ligation-dependent methods are relatively simple, we hypothesized that the ligationdependent method could be exploited to establish a one-step RNA detection platform when combined with compatible amplification and signal generation methods in a single reaction mixture.

In this study, we developed a one-step, ligation-dependent isothermal reaction cascade that enables rapid detection of RNAs with high sensitivity, termed SENsitive Splintbased one-step isothermal RNA detection (SENSR). SENSR consists of two simple enzymatic reactions, a ligation reaction by SplintR ligase and subsequent transcription by T7 RNA polymerase. The resulting transcript forms an RNA aptamer that binds to a fluorogenic dye and produces fluorescence only when target RNA exists in a sample. SENSR was able to detect target RNA of Methicillin-Resistant Staphylococcus aureus (MRSA) in 30 minutes with a limit of detection of $0.1 \mathrm{aM}$. We further applied this platform to detect various pathogens, Vibrio vulnificus, Escherichia coli O157:H7, Middle East Respiratory Syndromerelated Coronavirus (MERS-CoV), and Influenza A viruses, by merely redesigning the hybridization regions of the probes. Finally, we demonstrated the fast development of the SENSR assay for the latest epidemic pathogen, Severe acute respiratory syndrome-related coronavirus 2 (SARS-CoV-2 or 2019-nCoV), using minimal, publicly available information.

\section{Results}

\section{Design of one-step, isothermal reaction cascade}

We designed a reaction cascade that allows the one-step diagnostic test, in which all reaction steps for nucleic acid detection occur simultaneously in a single tube (Fig. 1). The cascade 
medRxiv preprint doi: https://doi.org/10.1101/2020.03.05.20031971; this version posted March 12,2020 . The copyright holder for this preprint (which was not certified by peer review) is the author/funder, who has granted medRxiv a license to display the preprint in All rights reserved. No reuse allowed without permission.

probes, SplintR ligase, T7 RNA polymerase, and a fluorogenic dye. The components were mixed in a buffer solution with ribonucleotides. Upon addition of the pathogen-derived RNA sample, the reaction steps of ligation, transcription, and dye-aptamer binding enabled detection, amplification, and signal production, respectively.

Two single-stranded DNA probes were designed to include several functional parts involved in amplification, detection, and signal generation, thereby eliminating the need for human intervention during the entire diagnostic process (Fig. 1). First, the promoter probe consists of an upstream hybridization sequence (UHS) and a stem-loop T7 promoter. The UHS hybridizes to the 5'-half of a target RNA region. The stem-loop T7 was adopted from the literature ${ }^{19}$ (Supplementary Table 1) to form an active, double-stranded T7 promoter using a single-stranded oligonucleotide. The sequence of the UHS was designed by PrimerBLAST $^{20}$ to ensure specific binding to the target RNA. Among candidate UHS sequences, we chose the one with minimal secondary structure at $37{ }^{\circ} \mathrm{C}$ predicted by NUPACK ${ }^{21}$ to maximize the hybridization between the UHS and its target region (Supplementary Table 2). The 5'-end of the promoter probe was then phosphorylated for ligation. Next, a reporter probe consists of a downstream hybridization sequence (DHS) and a template sequence for a dyebinding RNA aptamer. The DHS contains the complementary sequence to the other half of the target RNA region. Similar to the UHS, the DHS was selected to have minimal predicted secondary structure (Supplementary Table 2).

Once both UHS and DHS probes hybridize correctly to the target RNA, SplintR ligase can initiate the cascade by connecting the probes that have all features built for the onestep diagnostic test. Subsequently, T7 RNA polymerase can synthesize the RNA aptamer using the full-length, ligated probe as a DNA template, which can be bound with the fluorogenic dye to emit fluorescence as an output (Fig. 1). Notably, the reaction scheme of SENSR inherently supports two mechanisms that could amplify the signal: 1) multiple 
medRxiv preprint doi: https://doi.org/10.1101/2020.03.05.20031971; this version posted March 12, 2020. The copyright holder for this preprint (which was not certified by peer review) is the author/funder, who has granted medRxiv a license to display the preprint in All rights reserved. No reuse allowed without permission.

104 transcription events from the full-length, ligated probe by T7 RNA polymerase and 2) the

105 presence of target RNA sequence on the full-length transcript which could be utilized as an

106 additional splint for unligated probes in the reaction mixture. Accordingly, SENSR could

107 enable sensitive RNA detection without any pre-amplification steps.

\section{Construction of each component reaction in SENSR}

110 In this study, we used MRSA as a model case to validate each reaction step that constitutes

111 SENSR. MRSA is of particular interest because it requires significant effort to minimize

112 healthcare-related infections and prevent future infectious diseases of drug-resistant

113 pathogens ${ }^{22}$.

First, we designed a pair of probes that target the mecA transcript of MRSA following the probe design process described in the previous section (Supplementary Note 1 and tested. The probes were ligated using SplintR ligase with or without the target RNA, and the

118 reaction resultants were further amplified with a pair of PCR primers and analyzed (see

119 Methods section). The correct size of the PCR product was obtained only when the two

120 probes and target RNA were added together to the ligation mixture (Fig. 2a). This result

121 indicates that our probes were successfully ligated only in the presence of the target RNA. We then used the ligated probe as a DNA template to test whether transcription could occur. The ligation mixture was added at a 1/10 ratio to the in vitro transcription reaction

124 mixture with T7 RNA polymerase. Only when the target RNA was present in the ligation reaction was the full-length transcript (92 nt) observed from transcription, thereby confirming

126 both target-dependent ligation and the subsequent transcription (Fig. 2b). 
medRxiv preprint doi: https://doi.org/10.1101/2020.03.05.20031971; this version posted March 12, 2020. The copyright holder for this preprint (which was not certified by peer review) is the author/funder, who has granted medRxiv a license to display the preprint in All rights reserved. No reuse allowed without permission.

129 ligation and transcription reactions were purified, and an equal amount of RNAs from each

130 combination was incubated with the fluorogenic dye (Fig. 2c). The RNA product from the

131 reaction mixture with the two probes and target RNA produced higher fluorescence than that

132 of the other combinations. Therefore, we confirmed that the target RNA could be detected

133 using a set of probes by performing each component reaction in SENSR.

134

135 Development of one-step isothermal reaction cascade

136 Since all component reactions in SENSR were validated in their respective buffers, we then

137 sought to develop a one-step reaction condition with a single reaction buffer at a single

138 temperature, where all reaction steps, including probe annealing, ligation, transcription, and

139 aptamer fluorescence reaction occur simultaneously. To accomplish this, we first investigated

140 a wide range of temperatures $\left(25-95^{\circ} \mathrm{C}\right)$ for hybridization of the probes and target. Then,

141 each mixture was subjected to the sequential ligation, transcription reactions, and

142 fluorescence reaction described in the previous section. Remarkably, fluorescence was

143 observed at all hybridization temperatures, including $35^{\circ} \mathrm{C}$ and $40{ }^{\circ} \mathrm{C}$ (Supplementary Fig.

144 1), the optimal temperature ranges for enzyme activities in SENSR, thereby suggesting that

145 the entire reaction can be built up as an isothermal reaction.

146 Additionally, a single reaction buffer composition suitable for all reaction steps was

147 configured to establish all reactions in one pot. Since T7 RNA polymerase reaction buffer has

148 the most inclusive composition of the four reaction buffers (probe annealing, ligation,

149 transcription, and aptamer fluorescence reaction buffers) we used T7 RNA polymerase buffer

150 as a basis for the optimization. Various reaction conditions were optimized, including the

151 reaction temperature and concentrations of various enzymes, and components to enhance the

152 fluorescence signal (Supplementary Note 2 and Supplementary Figs. 2 and 3). The optimized 
medRxiv preprint doi: https://doi.org/10.1101/2020.03.05.20031971; this version posted March 12, 2020. The copyright holder for this preprint (which was not certified by peer review) is the author/funder, who has granted medRxiv a license to display the preprint in All rights reserved. No reuse allowed without permission.

153 SENSR condition enabled the detection of target RNA in a one-pot isothermal reaction at $15437^{\circ} \mathrm{C}$.

\section{Rapid and sensitive RNA detection by SENSR}

157 Since the one-step and one-pot isothermal reaction condition was established, we then

158 assessed the sensitivity and turnaround time of SENSR. We evaluated the sensitivity by

159 measuring fluorescence from one-step reactions containing the mecA probe pair and synthetic

160 mecA RNA in the range of 0.1 aM to $220 \mathrm{nM}$ (Fig. 3a). Notably, the detection limit was as

161 low as $0.1 \mathrm{aM}$ (corresponding to 6 molecules per $100 \mu \mathrm{L}$ reaction), indicating the high

162 sensitivity of SENSR. Moreover, the linearity of the fluorescence intensity over a wide range

163 of concentrations $\left(\mathrm{R}^{2}=0.9932\right)$ suggests that SENSR can be used for target RNA

164 quantification.

165 We then measured the minimal turnaround time required to confirm the presence of

166 the target RNA in a sample. The target RNA ranging from $0.1 \mathrm{aM}$ to $10 \mathrm{aM}$ were added to the

167 SENSR reaction, and fluorescence was measured every 30 minutes. The fluorescence with

1680.1 aM was discernible against the negative control in only 30 minutes (Fig. 3b). Further

169 incubation of the reaction better distinguished the target RNA-containing reaction from the

170 negative control reaction. Collectively, the SENSR reaction was able to specifically detect the

171 target RNA within 30 minutes with a detection limit of $0.1 \mathrm{aM}$.

\section{Broad adaptability of SENSR for pathogen detection}

174 With the fast and sensitive RNA detection using SENSR, we next attempted to reconfigure

175 this platform for the detection of RNA markers from various pathogens. Target RNA

176 sequences for SENSR are specified by only two hybridization regions (UHS and DHS) of

177 probes, which makes the probe design process fast and straightforward without many 
medRxiv preprint doi: https://doi.org/10.1101/2020.03.05.20031971; this version posted March 12, 2020. The copyright holder for this preprint (which was not certified by peer review) is the author/funder, who has granted medRxiv a license to display the preprint in All rights reserved. No reuse allowed without permission.

computational steps. This design feature, requiring only nucleotide sequences to build molecular diagnostics, allows for easy construction of SENSR probes for any infectious diseases (Fig. 4a).

To demonstrate SENSR for various pathogens, we first targeted two pathogenic microorganisms, V. vulnificus and E. coli O157:H7. V. vulnificus is known to cause gastroenteritis, wound infection, and sepsis in humans. We designed a probe pair targeting $v v h A$ (Supplementary Table 3), a $V$. vulnificus-specific target encoding extracellular hemolysin with hemolytic activity and cytotoxic effect. The sensitivity of SENSR reaction using the probe pair and in-vitro-transcribed $v v h A$ RNA was as low as $0.1 \mathrm{aM}$ (Fig. 4b), and a linear correlation was observed between the concentration of RNA and the fluorescence intensity $\left(\mathrm{R}^{2}=0.9566\right)$.

Next, we used SENSR to detect E. coli O157:H7, which causes foodborne illness. Similar to that for $V$. vulnificus, we designed a probe pair for E. coli $\mathrm{O} 157: \mathrm{H} 7$-specific target gene, tir (Supplementary Table 3), for SENSR reaction. Similarly, RNA concentrations as low as 0.1 aM were detected by SENSR and a high linear correlation between the concentration of RNA and the fluorescence intensity was observed (Fig. 4c; $\mathrm{R}^{2}=0.9684$ ). The target was expanded to human-infective RNA viruses that cause fatal diseases ${ }^{23}$. First, we aimed at Middle East Respiratory Syndrome-related Coronavirus (MERS-CoV). The mortality rate of MERS was reported to be $35 \%{ }^{24}$, and can be transmitted from human to human $^{25}$, which raises the need for a fast and sensitive onsite diagnostic test. The probe pairs for the MERS-specific gene, upE (Supplementary Table 3), exhibited similar sensitivity and linearity to the bacterial cases (Fig. 4d). Likewise, we designed a probe pair for the Influenza A virus-specific target gene, HA (hemagglutinin) gene (Supplementary Table 3). SENSR was able to detect the Influenza A RNA target with similar sensitivity and linearity (Fig. 4e).

Finally, we designed a probe pair for a recently emerging pathogen, SARS-CoV-2. The target 
medRxiv preprint doi: https://doi.org/10.1101/2020.03.05.20031971; this version posted March 12, 2020. The copyright holder for this preprint (which was not certified by peer review) is the author/funder, who has granted medRxiv a license to display the preprint in All rights reserved. No reuse allowed without permission.

sequence was selected based on the standard real-time RT-PCR assay for the SARS-CoV-2 ${ }^{26}$, which aimed at the RNA-dependent RNA polymerase ( $R d R p)$ gene (Supplementary Table 3). Again, SENSR successfully detected its target RNA as low as $0.1 \mathrm{aM}$, which corroborates the high adaptability of this method to various RNA markers (Fig. 2f).

Taken together, we demonstrated that SENSR could be easily reconfigured to detect various RNA markers of pathogens by redesigning the probes. The probe design process is simple and requires a small amount of computation using open web-based software. All probe pairs tested showed high sensitivity and linearity for detecting RNA markers, reinforcing the robustness of the probe design process and the wide expandability of SENSR.

\section{Direct detection of a pathogen using SENSR}

Next, we employed SENSR for the detection of RNA samples derived from the live cells of a pathogen. We targeted MRSA, whose marker RNA was detected by SENSR. MethicillinSensitive Staphylococcus aureus (MSSA) that contains no target mRNA was used as a negative control. MRSA and MSSA cells were heated to $95^{\circ} \mathrm{C}$ to lyse the cells and to release RNAs. The samples were then diluted and added to SENSR reaction to investigate the specificity and sensitivity (Fig. 5a). We observed a significant difference in fluorescence intensity between MRSA and MSSA (Fig. 5b). The RNA sample from only 2 CFU per 100 $\mu \mathrm{L}$ reaction of MRSA, not MSSA, was clearly detected by SENSR, thereby indicating its high sensitivity and specificity even with samples of the living pathogen. Finally, the performance of SENSR was further validated using samples prepared in human serum (Fig. 5c). The sensitivity and specificity of SENSR were unaffected by the presence of human serum (Fig. 5d), indicating the suitability of SENSR in practical applications.

\section{Dual target detection using orthogonal SENSR probes}


medRxiv preprint doi: https://doi.org/10.1101/2020.03.05.20031971; this version posted March 12, 2020. The copyright holder for this preprint (which was not certified by peer review) is the author/funder, who has granted medRxiv a license to display the preprint in All rights reserved. No reuse allowed without permission.

228 Finally, we expanded the capability of SENSR to enable the simultaneous detection of two 229 target RNAs in a single reaction by leveraging simple probe design. The detection of multiple 230 biomarkers is frequently needed to make a better decision by reducing false-positive and 231 false-negative results. Based on the high specificity of SENSR probes and availability of 232 light-up RNA aptamers with distinct spectral properties ${ }^{27}$, we hypothesized that we could 233 design two sets of SENSR probes that operate orthogonally in a single reaction to detect their 234 respective target RNAs.

First, we developed an orthogonal reporter probe for Influenza A virus. Since the

236 MRSA infection causes flu-like symptoms, discrimination of this pathogen from common 237 Influenza A virus is required. Furthermore, the patient with the influenza A infection is more 238 susceptible to the MRSA infection ${ }^{28}$. Collectively, simultaneous detection and discrimination 239 of both pathogens can help the diagnosis and follow-up actions. An orthogonal reporter probe 240 for Influenza A virus was designed by replacing its aptamer template region with the template 241 for the Broccoli aptamer ${ }^{29-32}$ which binds to DFHBI-1T ((5Z)-5-[(3,5-Difluoro-4242 hydroxyphenyl)methylene]-3,5-dihydro-2-methyl-3-(2,2,2-trifluoroethyl)-4H-imidazol-4243 one) and exhibits spectral properties distinct from that of the malachite green aptamer.

244 Secondary structures of the new reporter probe and corresponding full-length RNA transcript 245 were simulated, using NUPACK, and satisfied the probe design criteria without further 246 optimization (Supplementary Table 2). Dual detection of MRSA and Influenza A virus was 247 tested in SENSR reactions in which the two probe pairs, their cognate fluorogenic dyes, and 248 various concentrations of the target RNAs were added (Fig. 6a). When the probe pairs are 249 hybridized to their respective target RNAs, and successful transcription follows, the RNA 250 aptamers would bind their cognate dyes and emit distinguishable fluorescence. The presence 251 of each target RNA could be determined by the fluorescence patterns from the SENSR 252 reaction: malachite green aptamer fluorescence for MRSA, and Broccoli aptamer 
medRxiv preprint doi: https://doi.org/10.1101/2020.03.05.20031971; this version posted March 12, 2020. The copyright holder for this preprint (which was not certified by peer review) is the author/funder, who has granted medRxiv a license to display the preprint in All rights reserved. No reuse allowed without permission.

fluorescence for Influenza A virus. Indeed, the presence of either target RNA (1 nM) was easily detected by the fluorescence pattern (Fig. 6b). Across various concentrations of each target RNA, the SENSR probes specifically produced fluorescence that responded only to respective targets, thereby enabling orthogonal dual detection of two pathogens (Fig. 6c). related viruses with high sequence homology. Simultaneous detection of multiple target sites along its genome would enable specific discrimination of this emerging pathogen from others. In addition to the previously demonstrated SARS-CoV-2 probe pair (Fig. 4f), we designed three additional probe pairs for other regions in the $R d R p$ gene with either the malachite green aptamer or the Broccoli aptamer (Fig. 7a). Each probe pair contained a 263 discriminatory base at either the 5'-end of PP or 3'-end of RP, which are unique to SARSCoV-2 against other similar viruses. Mismatches between the probes and nontarget RNAs would inhibit ligation and subsequent SENSR reaction and could enable more specific detection of SARS-CoV-2. Indeed, all four probe pairs were able to detect 1 aM of SARSCoV-2 RNA, thereby exhibiting higher fluorescence intensity compared to that of the related viral RNA sequences (Fig. 7b). We then tested the orthogonal dual detection of two target regions using the SARS-CoV-2-MG1 and SARS-CoV-2-BR2 probe pairs. Dual SENSR assay effectively detected the target RNA and maintained the specificity of each probe pair

271 (Fig. 7c). Therefore, the dual SENSR assay could be used to assist diagnostic decision 272 making by providing two detection results that can complement each other.

\section{Discussion}

275 Rapid, simple, economical, and sensitive diagnostic tests are needed to detect and manage 276 infectious diseases at the earliest possible time. However, conventional approaches lack one 277 or more of these features. Culture-based methods are time-consuming $(>24 \mathrm{~h})^{33}$ while PCR- 
medRxiv preprint doi: https://doi.org/10.1101/2020.03.05.20031971; this version posted March 12, 2020. The copyright holder for this preprint (which was not certified by peer review) is the author/funder, who has granted medRxiv a license to display the preprint in All rights reserved. No reuse allowed without permission.

278 based methods, including real-time-PCR, require a complex procedure, expensive

279 instruments, and skilled expertise. Various isothermal amplification methods for RNA have

280 been introduced to replace traditional methods ${ }^{7,8}$, but they generally require numerous

281 reaction components, often making them expensive and incompatible with the signal

282 production step.

In contrast, SENSR satisfies many desirable requirements for onsite diagnostic tests

284 for pathogens, such as short turnaround time (30 min), low limit of detection $(0.1 \mathrm{aM})$,

285 inexpensive instrumentation and reagents, and a simple diagnostic procedure. SENSR

286 integrates all component reaction steps using the specially designed probes that contain all

287 required functional parts: promoter, hybridization sequence to target, and an aptamer

288 template. Even with the multifaceted features of the SENSR probes, the design process is

289 systematic and straightforward. Therefore, new SENSR assay can be promptly developed for

290 emerging pathogens as exemplified by the successful design of SENSR assay for SARS-

291 CoV-2.

The probe design is unique in that two DNA probes are designed to expose single-

293 stranded target recognition parts, enabling hybridization of the target RNA and the probes at

$29437^{\circ} \mathrm{C}$. The hybridization sequences were systematically selected using the nucleic acid design

295 software Primer-BLAST and NUPACK to minimize any structure formation while

296 maximizing hybridization to the target RNA. The efficient hybridization between the probes

297 and target RNA is one of the reasons for enabling high sensitivity during the isothermal

298 reaction.

The promoter probe is programmed to form a stem-loop structure and the stem part

300 forms a double-stranded T7 promoter sequence that initiates transcription by recruiting T7

301 RNA polymerase. Since the two strands of T7 promoter part are physically connected by the

302 loop, the probability of formation of a functional double-stranded promoter is higher in the 
medRxiv preprint doi: https://doi.org/10.1101/2020.03.05.20031971; this version posted March 12, 2020. The copyright holder for this preprint (which was not certified by peer review) is the author/funder, who has granted medRxiv a license to display the preprint in All rights reserved. No reuse allowed without permission.

stem-loop structured design than when each strand of the promoter is not connected by the loop. Thus, the hairpin structured, self-assembling promoter sequence in the promoter probe can facilitate hybridization and subsequent transcription more efficiently.

The initiated transcription elongates through the single-stranded DNA as a template to amplify target RNAs containing aptamer RNAs. The use of a fluorogenic RNA aptamer facilitated SENSR development by enabling fast and straightforward signal generation. Compared to conventional fluorescent protein outputs, the use of RNA aptamers as reporters can reduce the time it takes to observe the signal ${ }^{34}$.

The simple enzyme composition is another reason to enable one-step and one-pot detection. The fewer the enzymes, the easier it is to optimize in terms of temperature and buffer composition. In designing the detection scheme, we deliberately tried to reduce the number of enzymes, thus creating one of the simplest isothermal detection schemes based on two enzymes: SplintR ligase for target detection and T7 RNA polymerase for amplification. In addition to the results shown in this study, we expect that SENSR has a broad range of possibilities for pathogen detection. First, SENSR can be easily implemented in the initial screening of infectious diseases at places where a large number of people gather and transfer ${ }^{35,36}$. With a short turnaround time and a simple reaction composition, SENSR is an ideal diagnostic test for rapid and economical screening. Second, SENSR will be a valuable platform for the immediate development of diagnostic tests for emerging pathogens ${ }^{1,37}$ because of the simple probe design process and broad adaptability of SENSR. In this work, we demonstrated the successful application of SENSR to six pathogens, using minimal redesign based on the highly modular structure of the probes. In theory, SENSR detection probes can be designed for any RNA as long as the target nucleic acid sequence is available. This feature provides SENSR a significant advantage over antibody-based diagnostics to rapidly respond to the outbreak of infectious disease. The nucleic acid probe synthesis is 
medRxiv preprint doi: https://doi.org/10.1101/2020.03.05.20031971; this version posted March 12, 2020. The copyright holder for this preprint (which was not certified by peer review) is the author/funder, who has granted medRxiv a license to display the preprint in All rights reserved. No reuse allowed without permission.

328 more scalable than animal antibody production. Therefore, SENSR is more suitable for rapid 329 mass production of diagnostic kits than antibody-based diagnostics. Future efforts on 330 automated probe design will be needed to accelerate the development of SENSR assays for 331 newly emerging pathogens.

332 In conclusion, SENSR is a powerful diagnostic platform for RNA detection, which 333 offers a short turnaround time, high sensitivity and specificity, and a simple assay procedure, 334 and eliminates the need for expensive instrumentations and diagnostic specialists. Given the 335 simple probe design process, and its rapid development, SENSR will be a suitable diagnostic 336 method for emerging infectious diseases. 
medRxiv preprint doi: https://doi.org/10.1101/2020.03.05.20031971; this version posted March 12,2020 . The copyright holder for this preprint (which was not certified by peer review) is the author/funder, who has granted medRxiv a license to display the preprint in All rights reserved. No reuse allowed without permission.

\section{Methods}

338 Materials. SplintR ligase, T7 RNA polymerase, extreme thermostable single-stranded DNA 339 binding protein (ET-SSB), DNase I (RNase-free), and ribonucleotide solution mix were

340 obtained from New England Biolabs (NEB, Ipswich, MA, USA). Recombinant RNase

341 Inhibitor and pMD20 T-vector were obtained from Takara (Shiga, Japan). Malachite green

342 oxalate was purchased from Sigma-Aldrich (St. Louis, MO, USA). Dithiothreitol was

343 acquired from Thermo Fisher Scientific (Waltham, MA, USA). Potassium chloride and 5'-

344 phosphate modified oligonucleotides were obtained from Bioneer, Inc. (Daejeon, Republic of

345 Korea). Full-length probe oligonucleotides were synthesized from Integrated DNA

346 Technologies, Inc. (IDT, Coralville, IA, USA). Oligonucleotides other than these were

347 synthesized from Cosmogenetech, Inc. (Seoul, Republic of Korea).

349 Preparation of target RNA. Target RNA was synthesized by an in vitro transcription

350 process. To accomplish this, the template DNA containing the target RNA region was

351 amplified by PCR with primer, including the T7 promoter sequence, and cloned into pMD20

352 T-vector. The PCR amplicon was used as a template for in vitro transcription. A transcription

353 reaction mixture containing $1 \mu \mathrm{g}$ of target DNA, $2 \mu \mathrm{L} 10 \times \mathrm{T} 7 \mathrm{RNA}$ polymerase reaction

354 buffer, $1 \mu \mathrm{L}$ DTT ( $1 \mathrm{mM}), 0.8 \mu \mathrm{L}$ NTPs (1 mM for each NTP), $0.5 \mu \mathrm{L}$ Recombinant RNase

355 Inhibitor (20 U), $2 \mu \mathrm{L} \mathrm{T7}$ RNA polymerase (50 U), and $8.7 \mu \mathrm{L}$ RNase-free water was

356 incubated at $37^{\circ} \mathrm{C}$ for $16 \mathrm{~h}$. The resulting reaction products were treated with $1 \mu \mathrm{L}$ of DNase

357 I (RNase-free) for $1 \mathrm{~h}$ at $37^{\circ} \mathrm{C}$. The transcript was purified using the Riboclear ${ }^{\mathrm{TM}}$ (plus!)

358 RNA kit (GeneAll, Seoul, Republic of Korea) and quantified using the absorbance at $260 \mathrm{~nm}$.

359 The purified RNA was used immediately for the downstream reaction or stored at $-80{ }^{\circ} \mathrm{C}$. The 360 RNA transcripts were assessed by an Agilent 2100 Bioanalyzer (Agilent Technologies, Santa 
medRxiv preprint doi: https://doi.org/10.1101/2020.03.05.20031971; this version posted March 12, 2020. The copyright holder for this preprint (which was not certified by peer review) is the author/funder, who has granted medRxiv a license to display the preprint in All rights reserved. No reuse allowed without permission.

361 Clara, CA, USA) using an RNA 6000 nano kit (Agilent Technologies) following the manufacturer's direction. All primers are listed in Supplementary Table 4.

Preparation of MSSA and MRSA cell lysates. MRSA (NCCP 15919) and MSSA (NCCP 11488) were obtained from the Korea Centers for Disease Control and Prevention (Osong, Republic of Korea) and cultured for $24 \mathrm{~h}$ at $37{ }^{\circ} \mathrm{C}$ in $5 \%$ sheep blood agar (SBA) (Hanil Komed, Seoul, Republic of Korea). Cells were heat lysed at $95{ }^{\circ} \mathrm{C}$ for $2 \mathrm{~min}$.

Preparation of proxy clinical sample. Human serum was purchased from EMD Millipore Corporation (Temecula, CA, USA). MRSA (NCCP 15919) and MSSA (NCCP 11488) were spiked into human serum. Human serum was diluted at a 1/7 ratio in RNase-free water ${ }^{9}$ and the diluted human serum was heat lysed at $95^{\circ} \mathrm{C}$ for $2 \mathrm{~min}$.

RNA-splinted ssDNA ligation assay. The ligation reaction was performed according to a previously reported method ${ }^{17}$. In summary, $200 \mathrm{nM}$ PP, $220 \mathrm{nM}$ RP, and $220 \mathrm{nM}$ target RNA were added to $4 \mu \mathrm{L}$ reaction buffer containing $10 \mathrm{mM}$ Tris- $\mathrm{HCl}(\mathrm{pH} 7.4)$, and $50 \mathrm{mM} \mathrm{KCl}$ in RNase-free water. The mixture was heated to $95^{\circ} \mathrm{C}$ for $3 \mathrm{~min}$, then slowly cooled to room temperature. This was followed by the addition of $1 \mu \mathrm{L} 10 \mathrm{x}$ SplintR buffer and $0.5 \mu \mathrm{L}$ of SplintR ligase (25 U), and incubation of the mixture at $37^{\circ} \mathrm{C}$ for $30 \mathrm{~min}$. The reaction was 380 terminated by heating at $95{ }^{\circ} \mathrm{C}$ for $10 \mathrm{~min}$. The ligated product was amplified through PCR 381 reaction with LigChk_F and LigChk_R primers (Supplementary Table 4). The PCR products 382 were assessed by an Agilent 2100 Bioanalyzer using a DNA 1000 kit (Agilent Technologies) 383 according to the manufacturer's protocol. 
medRxiv preprint doi: https://doi.org/10.1101/2020.03.05.20031971; this version posted March 12, 2020. The copyright holder for this preprint (which was not certified by peer review) is the author/funder, who has granted medRxiv a license to display the preprint in All rights reserved. No reuse allowed without permission.

Malachite green and aptamer binding assay. A $1 \mu \mathrm{M}$ solution of RNA transcript containing malachite green aptamer was mixed with a reaction buffer $(50 \mathrm{mM}$ Tris- $\mathrm{HCl}$ at $\mathrm{pH}$ 7.5, $1 \mathrm{mM}$ ATP, $10 \mathrm{mM} \mathrm{NaCl}$, and $140 \mathrm{mM} \mathrm{KCl}$ ) to produce $90 \mu \mathrm{L}$ of solution. The mixture was heated to $95{ }^{\circ} \mathrm{C}$ for $10 \mathrm{~min}$ and left at room temperature for $20 \mathrm{~min}$. A $5 \mu \mathrm{L}$ solution of $10 \mathrm{mM} \mathrm{MgCl} 2$ was added to the mixture and allowed to stabilize at room temperature for 15 min, followed by addition of $5 \mu \mathrm{L}$ of $320 \mu \mathrm{M}$ malachite green solution to produce a total volume of $100 \mu \mathrm{L}$. The mixture was incubated at room temperature for $30 \mathrm{~min}$. After incubation, fluorescence intensity was measured using a microplate reader (Hidex, Lemminkäisenkatu, Finland) in 384-well clear flat-bottom black polystyrene microplates (Corning Inc., Corning, NY, USA). For the malachite green aptamer fluorescence, the excitation wavelength was $616 \mathrm{~nm}$ with a slit width of $8.5 \mathrm{~nm}$, and the emission wavelength was $665 \mathrm{~nm}$ with a slit width of $7.5 \mathrm{~nm}$. Background intensity from the malachite green buffer containing $16 \mu \mathrm{M}$ malachite green was subtracted from all fluorescence intensities.

SENSR protocol. The one-step, isothermal reaction master mix consisted of the following components: $2 \mu \mathrm{L}$ of $1 \mu \mathrm{M}$ PP, $2.2 \mu \mathrm{L}$ of $1 \mu \mathrm{M}$ RP, $5 \mu \mathrm{L}$ of $320 \mu \mathrm{M}$ malachite green solution (or $20 \mu \mathrm{L}$ of $50 \mu \mathrm{M}$ DFHBI-1T solution), $0.8 \mu \mathrm{L}$ of ET-SSB, $0.5 \mu \mathrm{L}$ Recombinant RNase Inhibitor (20 U), $10 \mu \mathrm{L}$ of SplintR ligase, $5 \mu \mathrm{L}$ of T7 RNA polymerase (50 U), and $10 \mu \mathrm{L}$ of $10 \times$ SENSR buffer containing $50 \mathrm{mM}$ Tris- $\mathrm{HCl}\left(\mathrm{pH}\right.$ 7.4), $10 \mathrm{mM} \mathrm{MgCl}_{2}, 1 \mathrm{mM}$ of each NTPs, and $10.5 \mathrm{mM} \mathrm{NaCl}$. The reaction master mix was adjusted to $99.22 \mu \mathrm{L}$ in RNase-free water and $0.78 \mu \mathrm{L}$ of target RNA was added to produce a total volume of $100 \mu \mathrm{L}$. The reaction solution was incubated at $37^{\circ} \mathrm{C}$ for $2 \mathrm{hr}$. After incubation, fluorescence intensity was measured by a Hidex Sense Microplate Reader, as described above. Background intensity from the SENSR buffer containing $16 \mu \mathrm{M}$ malachite green was subtracted from all malachite green fluorescence intensities. For the Broccoli aptamer fluorescence, the excitation 
medRxiv preprint doi: https://doi.org/10.1101/2020.03.05.20031971; this version posted March 12, 2020. The copyright holder for this preprint (which was not certified by peer review) is the author/funder, who has granted medRxiv a license to display the preprint in All rights reserved. No reuse allowed without permission.

410 wavelength was $460 \mathrm{~nm}$ with a slit width of $20 \mathrm{~nm}$, and the emission wavelength was $520 \mathrm{~nm}$

411 with a slit width of $14 \mathrm{~nm}$. Background intensity from the $10 \mu \mathrm{M}$ DFHBI-1T solution was

412 subtracted from all DFHBI-1T fluorescence intensities.

$413 \quad$ For dual detection, we used the following reaction mixture: $2 \mu \mathrm{L}$ of $1 \mu \mathrm{M}$ PP1, $2.2 \mu \mathrm{L}$

414 of $1 \mu \mathrm{M}$ RP1, $2 \mu \mathrm{L}$ of $1 \mu \mathrm{M}$ PP2, $2.2 \mu \mathrm{L}$ of $1 \mu \mathrm{M}$ RP2, $5 \mu \mathrm{L}$ of $320 \mu \mathrm{M}$ malachite green

415 solution, $20 \mu \mathrm{L}$ of $50 \mu \mathrm{M}$ DFHBI-1T solution, $0.8 \mu \mathrm{L}$ of ET-SSB, $0.5 \mu \mathrm{L}$ Recombinant

416 RNase Inhibitor (20 U), $10 \mu \mathrm{L}$ of SplintR ligase, $5 \mu \mathrm{L}$ of T7 RNA polymerase (50 U), and 10

$417 \mu \mathrm{L}$ of $10 \times$ SENSR buffer. The reaction master mix was adjusted to $99.22 \mu \mathrm{L}$ in RNase-free

418 water and added to $0.78 \mu \mathrm{L}$ of target RNA, producing a total volume $100 \mu \mathrm{L}$. The remaining

419 steps are identical to the single target detection.

420 
medRxiv preprint doi: https://doi.org/10.1101/2020.03.05.20031971; this version posted March 12, 2020. The copyright holder for this preprint (which was not certified by peer review) is the author/funder, who has granted medRxiv a license to display the preprint in All rights reserved. No reuse allowed without permission.

\section{Acknowledgments}

422 This research was supported by C1 Gas Refinery Program through the National Research

423 Foundation of Korea (NRF) funded by the Ministry of Science and ICT (NRF-

2015M3D3A1A01064926). This work was also supported by an NRF grant funded by the

Korea government (MSIT) (No. 2018R1C1B3007409). This research was also supported by

"Human Resources Program in Energy Technology" of the Korea Institute of Energy

Technology Evaluation and Planning (KETEP), which granted financial resource from the

Ministry of Trade, Industry \& Energy, Republic of Korea (No. 20194030202330).

\section{Author information}

\section{Chang Ha Woo and Sungho Jang}

432 These authors contributed equally to this work

\section{Affiliations}

434 School of Interdisciplinary Bioscience and Bioengineering, Pohang University of Science and

435 Technology, 77 Cheongam-ro, Nam-gu, Pohang, Gyeongbuk 37673, Korea

436 Chang Ha Woo, Giyoung Shin, Gyoo Yeol Jung \& Jeong Wook Lee

437 Department of Chemical Engineering, Pohang University of Science and Technology, 77

438 Cheongam-ro, Nam-gu, Pohang, Gyeongbuk 37673, Korea

439 Sungho Jang, Gyoo Yeol Jung \& Jeong Wook Lee

$440 \quad$ Present address

441 Department of Biomedical Engineering and Biological Design Center, Boston University,

442 Boston, MA 02215, USA

$443 \quad$ Sungho Jang

\section{Author contributions}


medRxiv preprint doi: https://doi.org/10.1101/2020.03.05.20031971; this version posted March 12, 2020. The copyright holder for this preprint (which was not certified by peer review) is the author/funder, who has granted medRxiv a license to display the preprint in All rights reserved. No reuse allowed without permission.

445 J.W.L. conceived the project. C.H.W., S.J., G.S., G.Y.J., and J.W.L. designed the experiment.

446 C.H.W., S.J., and G.S. performed the experiments. C.H.W., S.J., G.S., G.Y.J., and J.W.L.

447 analyzed the results. C.H.W., S.J., G.S., G.Y.J., and J.W.L. wrote the manuscript.

\section{Competing interests}

449 C.H.W., S.J., G.S., G.Y.J., \& J.W.L. have submitted a provisional patent application (No. 10450 2019-0046713) relating to the one-step isothermal RNA detection.

\section{Correspondence}

452 Correspondence to Jeong Wook Lee and Gyoo Yeol Jung. 
medRxiv preprint doi: https://doi.org/10.1101/2020.03.05.20031971; this version posted March 12, 2020. The copyright holder for this preprint (which was not certified by peer review) is the author/funder, who has granted medRxiv a license to display the preprint in All rights reserved. No reuse allowed without permission.

453

454

455

456

457

458

459

460

461

462

463

464

465

466

467

468

469

470

471

472

473

474

475

476

477

\section{References}

1. Caliendo, A. M. et al. Better tests, better care: improved diagnostics for infectious diseases. Clin Infect Dis 57 Suppl 3, S139-70 (2013).

2. Rajapaksha, P. et al. A review of methods for the detection of pathogenic microorganisms. Analyst (Lond) 144, 396-411 (2019).

3. Sintchenko, V. \& Gallego, B. Laboratory-guided detection of disease outbreaks: three generations of surveillance systems. Arch Pathol Lab Med 133, 916-925 (2009).

4. O’Connor, L. \& Glynn, B. Recent advances in the development of nucleic acid diagnostics. Expert Rev Med Devices 7, 529-539 (2010).

5. Pavšič, J. et al. Standardization of nucleic acid tests for clinical measurements of bacteria and viruses. J Clin Microbiol 53, 2008-2014 (2015).

6. Dong, J., Olano, J. P., McBride, J. W. \& Walker, D. H. Emerging pathogens: challenges and successes of molecular diagnostics. J Mol Diagn 10, 185-197 (2008).

7. Zhao, Y., Chen, F., Li, Q., Wang, L. \& Fan, C. Isothermal amplification of nucleic acids. Chem Rev 115, 12491-12545 (2015).

8. Yan, L. et al. Isothermal amplified detection of DNA and RNA. Mol Biosyst 10, 9701003 (2014).

9. Pardee, K. et al. Rapid, Low-Cost Detection of Zika Virus Using Programmable Biomolecular Components. Cell 165, 1255-1266 (2016).

10. Gootenberg, J. S. et al. Nucleic acid detection with CRISPR-Cas13a/C2c2. Science 356, 438-442 (2017).

11. Gootenberg, J. S. et al. Multiplexed and portable nucleic acid detection platform with Cas13, Cas12a, and Csm6. Science 360, 439-444 (2018).

12. Cao, W. Recent developments in ligase-mediated amplification and detection. Trends 
medRxiv preprint doi: https://doi.org/10.1101/2020.03.05.20031971; this version posted March 12, 2020. The copyright holder for this preprint (which was not certified by peer review) is the author/funder, who has granted medRxiv a license to display the preprint in All rights reserved. No reuse allowed without permission.

Biotechnol 22, 38-44 (2004).

13. Stuppia, L., Antonucci, I., Palka, G. \& Gatta, V. Use of the MLPA assay in the molecular diagnosis of gene copy number alterations in human genetic diseases. Int $J$ Mol Sci 13, 3245-3276 (2012).

14. Shin, G. W. et al. Stuffer-free multiplex ligation-dependent probe amplification based on conformation-sensitive capillary electrophoresis: a novel technology for robust multiplex determination of copy number variation. Electrophoresis 33, 3052-3061 (2012).

15. Chung, B. et al. Rapid and sensitive detection of lower respiratory tract infections by stuffer-free multiplex ligation-dependent probe amplification. Electrophoresis 35, 511$514(2014)$.

16. Chung, B. et al. Precise H1N1 swine influenza detection using stuffer-free multiplex ligation-dependent probe amplification in conformation-sensitive capillary electrophoresis. Anal Biochem 424, 54-56 (2012).

17. Jin, J., Vaud, S., Zhelkovsky, A. M., Posfai, J. \& McReynolds, L. A. Sensitive and specific miRNA detection method using SplintR Ligase. Nucleic Acids Res 44, e116 (2016).

18. Ying, Z.-M. et al. Spinach-based fluorescent light-up biosensors for multiplexed and label-free detection of microRNAs. Chem Commun (Camb) 54, 3010-3013 (2018).

19. Kukarin, A., Rong, M. \& McAllister, W. T. Exposure of T7 RNA polymerase to the isolated binding region of the promoter allows transcription from a single-stranded template. J Biol Chem 278, 2419-2424 (2003).

20. National Center for Biotechnology Information. Primer-BLAST. at <https://www.ncbi.nlm.nih.gov/tools/primer-blast/index.cgi>

21. Zadeh, J. N. et al. NUPACK: Analysis and design of nucleic acid systems. J Comput 
medRxiv preprint doi: https://doi.org/10.1101/2020.03.05.20031971; this version posted March 12, 2020. The copyright holder for this preprint (which was not certified by peer review) is the author/funder, who has granted medRxiv a license to display the preprint in All rights reserved. No reuse allowed without permission.

Chem 32, 170-173 (2011).

22. Marlowe, E. M. \& Bankowski, M. J. Conventional and Molecular Methods for the Detection of Methicillin-Resistant Staphylococcus aureus. J Clin Microbiol 49, S53-S56 (2011).

23. Woolhouse, M. E. J. \& Brierley, L. Epidemiological characteristics of human-infective RNA viruses. Scientific data 5, 180017 (2018).

24. Alsolamy, S. \& Arabi, Y. M. Infection with Middle East respiratory syndrome coronavirus. Canadian journal of respiratory therapy : CJRT $=$ Revue canadienne de la thérapie respiratoire: $R C T R$ 51, 102 (2015).

25. Mackay, I. M. \& Arden, K. E. MERS coronavirus: diagnostics, epidemiology and transmission. Virol J 12, 222 (2015).

26. Victor/Charité Virology, C. et al. Diagnostic detection of 2019-nCoV by real-time RTPCR. Diagnostic detection of 2019-nCoV by real-time RT-PCR (2020). at <https://www.who.int/docs/default-source/coronaviruse/protocol-v2-

27. Bouhedda, F., Autour, A. \& Ryckelynck, M. Light-Up RNA Aptamers and Their Cognate Fluorogens: From Their Development to Their Applications. Int J Mol Sci 19,

28. Mulcahy, M. E. \& McLoughlin, R. M. Staphylococcus aureus and Influenza A Virus: Partners in Coinfection. MBio 7, (2016).

29. Filonov, G. S., Moon, J. D., Svensen, N. \& Jaffrey, S. R. Broccoli: rapid selection of an RNA mimic of green fluorescent protein by fluorescence-based selection and directed evolution. J Am Chem Soc 136, 16299-16308 (2014). 
medRxiv preprint doi: https://doi.org/10.1101/2020.03.05.20031971; this version posted March 12, 2020. The copyright holder for this preprint (which was not certified by peer review) is the author/funder, who has granted medRxiv a license to display the preprint in All rights reserved. No reuse allowed without permission. and Mammalian Cells. Curr Protoc Chem Biol 8, 1-28 (2016).

31. Okuda, M., Fourmy, D. \& Yoshizawa, S. Use of Baby Spinach and Broccoli for imaging of structured cellular RNAs. Nucleic Acids Res 45, 1404-1415 (2017).

32. Torelli, E. et al. Isothermal folding of a light-up bio-orthogonal RNA origami nanoribbon. Sci. Rep. 8, 6989 (2018).

33. Sinha, M. et al. Emerging technologies for molecular diagnosis of sepsis. Clin Microbiol $\operatorname{Rev}$ 31, (2018).

34. Alam, K. et al. Rapid, Low-Cost Detection of Water Contaminants Using Regulated In Vitro Transcription. BioRxiv (2019). doi:10.1101/619296

35. Gaber, W., Goetsch, U., Diel, R., Doerr, H. W. \& Gottschalk, R. Screening for infectious diseases at international airports: the frankfurt model. Aviat Space Environ Med 80, 595600 (2009).

36. Khan, K. et al. Entry and exit screening of airline travellers during the A(H1N1) 2009 pandemic: a retrospective evaluation. Bull World Health Organ 91, 368-376 (2013).

540 37. Identification and Diagnosis of Newly Emerging Pathogens. Infectious Diseases and Translational Medicine (2017). 


\section{Figures}

544 Fig. 1

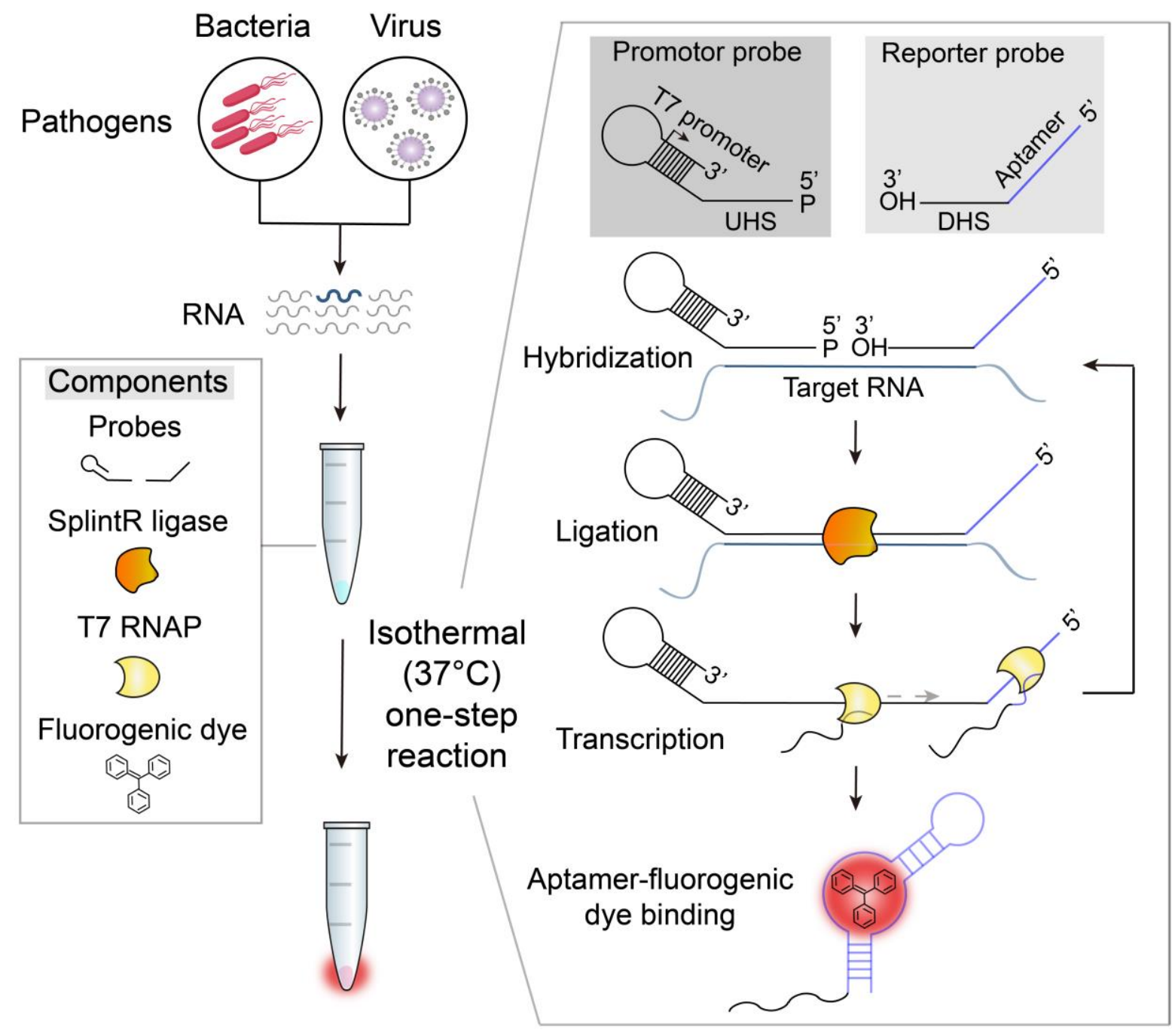

546 Fig. 1: Schematic illustration of SENSR, a one-step isothermal reaction cascade for

547 rapid detection of RNAs. The reaction is composed of four main components: a set of

548 probes, SplintR ligase, T7 RNA polymerase (T7 RNAP), and a fluorogenic dye. In the

549 presence of target RNA, hybridization, ligation, transcription, and aptamer-dye binding

550 reactions occur sequentially in a single reaction tube at a constant temperature. UHS,

551 upstream hybridization sequence; DHS, downstream hybridization sequence. 
medRxiv preprint doi: https://doi.org/10.1101/2020.03.05.20031971; this version posted March 12, 2020. The copyright holder for this preprint (which was not certified by peer review) is the author/funder, who has granted medRxiv a license to display the preprint in All rights reserved. No reuse allowed without permission.

Fig. 2

\section{a Ligation}

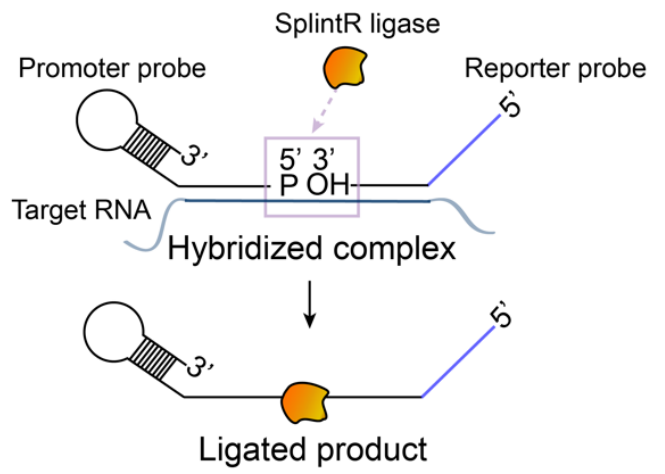

\section{b Transcription}

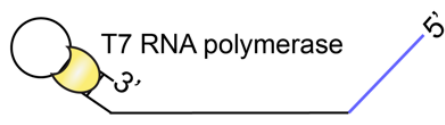

Ligated product (Transcript template)

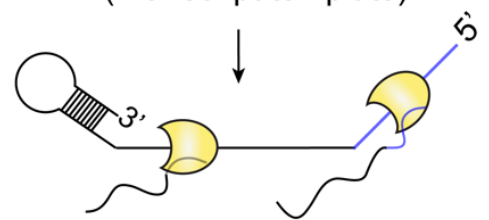

Partial transcript Full-length transcript
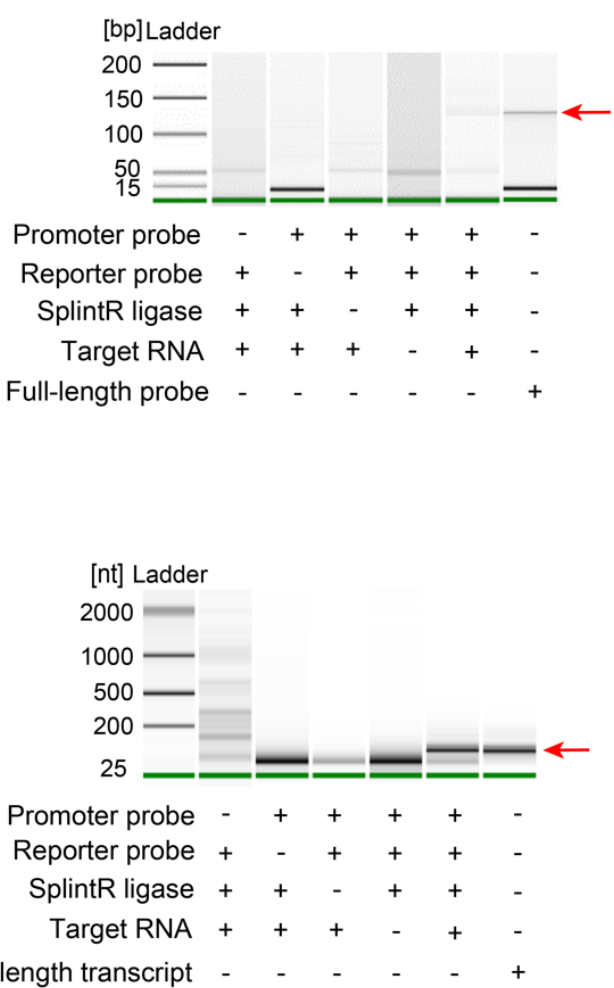

Full-length transcript

\section{Aptamer-fluorogenic dye binding}
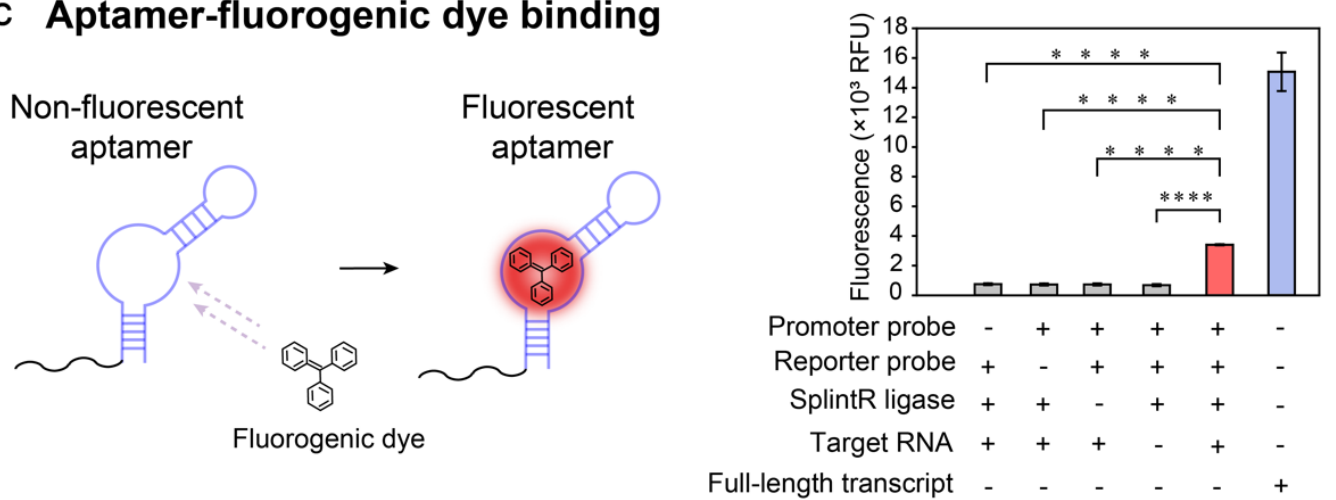

554 Fig. 2: Construction of the three components reactions of SENSR. a, Ligation reaction.

555 The ligation resultants were amplified with a pair of PCR primers (LigChk_F,R in

556 Supplementary Table 4) and analyzed using Bioanalyzer. The ligation reaction occurred

557 when only the promoter probe, reporter probe, SplintR ligase, and target RNA were all present. A full-length probe combining the promoter and reporter probes was amplified with 
medRxiv preprint doi: https://doi.org/10.1101/2020.03.05.20031971; this version posted March 12, 2020. The copyright holder for this preprint (which was not certified by peer review) is the author/funder, who has granted medRxiv a license to display the preprint in All rights reserved. No reuse allowed without permission.

559 the same set of PCR primers and used as a size control, as indicated by the red arrow. $\mathbf{b}$,

560 Transcription reaction. The ligated mixtures were used as a DNA template to validate

561 transcription. The transcript was obtained only in the presence of target RNA and all other

562 components, demonstrating both target-dependent ligation and the subsequent transcription.

563 The red arrow points to the correct size of the transcript. c, Fluorescence reaction. After

564 sequential ligation and transcription reactions, the reaction mixture with the correct size of

565 the transcript produced higher fluorescence compared to other conditions that lack one of the

566 necessary components. Fluorescence tests are four experimental replicas (two-tailed student's

567 test; $* \mathrm{P}<0.05, * * \mathrm{P}<0.01, * * * \mathrm{P}<0.001$, **** $\mathrm{P}<0.0001$; bars represent mean $\pm \mathrm{s} . \mathrm{d})$. 
medRxiv preprint doi: https://doi.org/10.1101/2020.03.05.20031971; this version posted March 12,2020 . The copyright holder for this preprint (which was not certified by peer review) is the author/funder, who has granted medRxiv a license to display the preprint in All rights reserved. No reuse allowed without permission.

Fig. 3

a Sensitivity

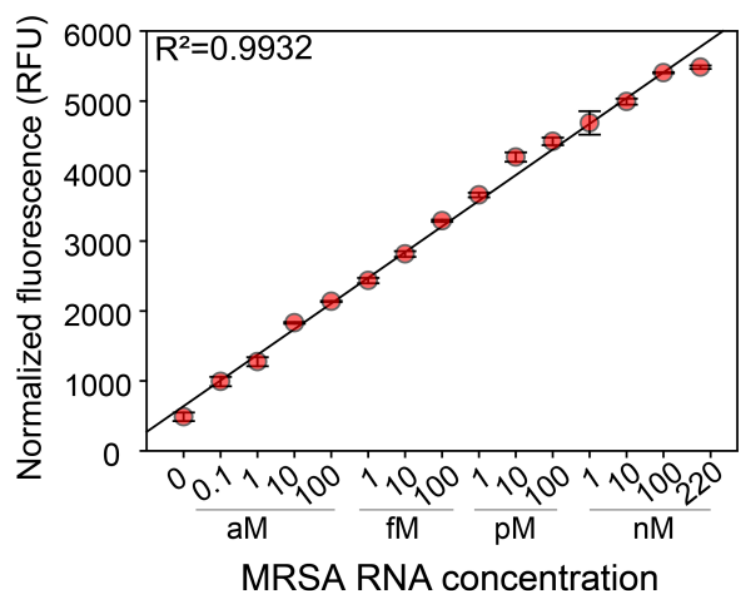

b Turnaround time

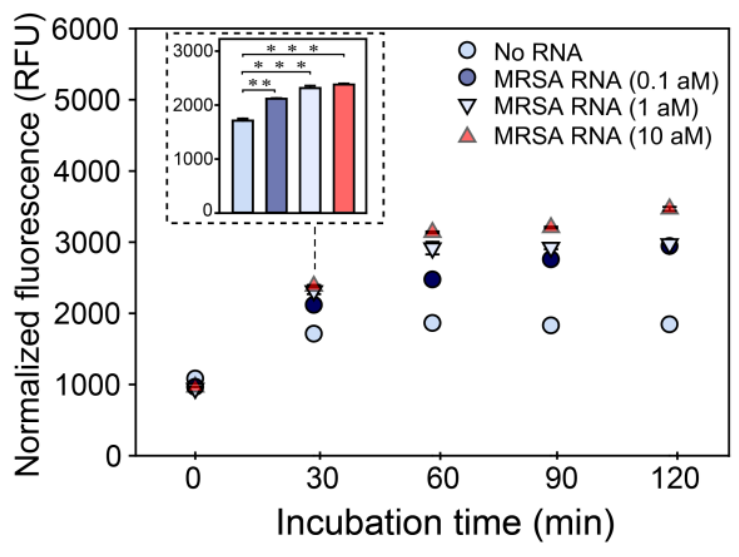

570 Fig. 3: Sensitivity and turnaround time of SENSR. a, Sensitivity of SENSR. The target

571 RNA from $220 \mathrm{nM}$ to $0.1 \mathrm{aM}$ was tested. The detection limit is $0.1 \mathrm{aM}$. High linearity

572 suggests that SENSR can be used for the quantification of the target RNA. b, Turnaround

573 time of SENSR. To check the time required for the SENSR reaction, the incubation time of

574 SENSR was varied. The target RNA of $0.1 \mathrm{aM}$ was detected as early as $30 \mathrm{~min}$. All tests are

575 four experimental replicas (two-tailed student's test; * $\mathrm{P}<0.05$, ** $\mathrm{P}<0.01$, *** $\mathrm{P}<0.001$, $* * * * \mathrm{P}<0.0001$; bars represent mean \pm s.d). 
medRxiv preprint doi: https://doi.org/10.1101/2020.03.05.20031971; this version posted March 12, 2020. The copyright holder for this preprint (which was not certified by peer review) is the author/funder, who has granted medRxiv a license to display the preprint in All rights reserved. No reuse allowed without permission.

a
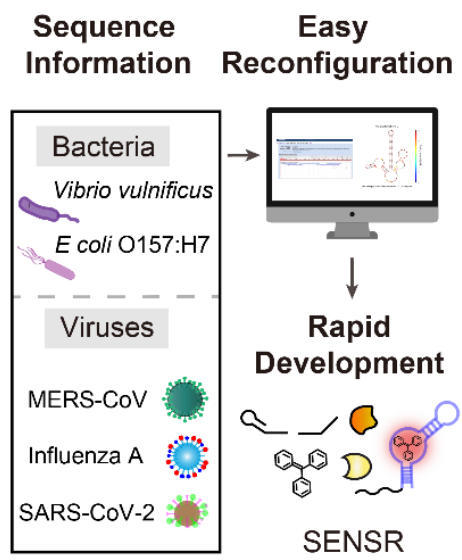

d

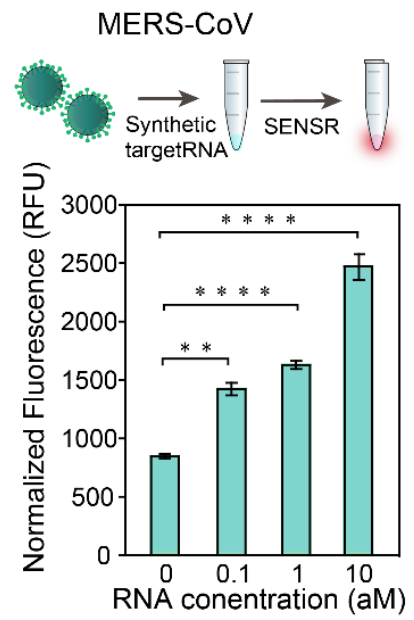

b

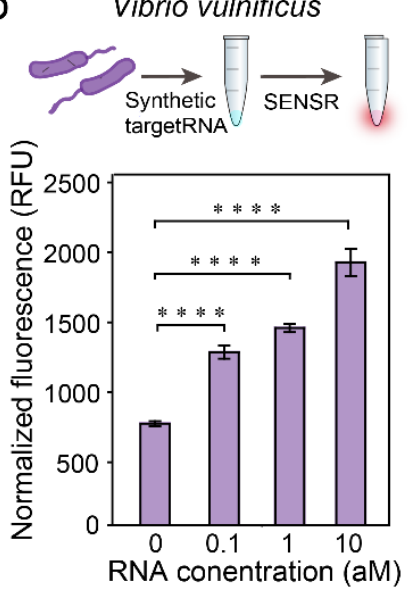

e
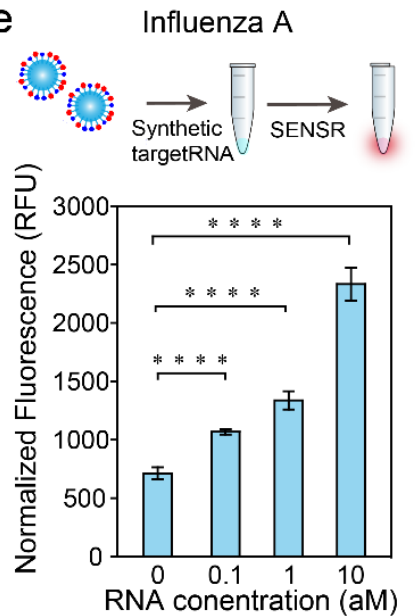
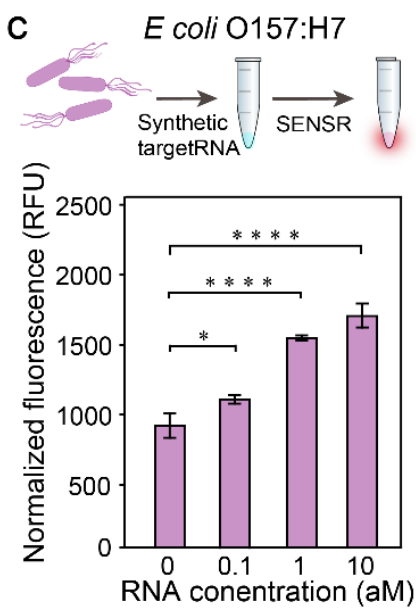

f

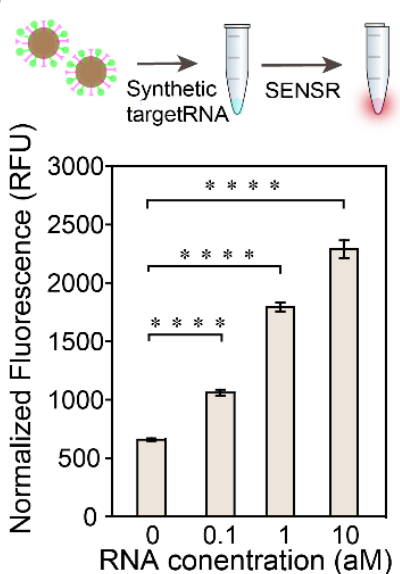

579 Fig. 4: Broad adaptability of SENSR. Two pathogenic microbes and three viruses were

580 targeted by redesigning probe sequences. a, Schematic of SENSR with easy reconfiguration

581 and rapid development. b,c, Detection of bacterial RNA markers, for $V$. vulnificus and E. coli

582 O157:H7, respectively. d,e,f, Detection of viral RNA markers, MERS-CoV, Influenza A, and

583 SARS-CoV-2, respectively. All probe pairs tested showed high sensitivity and linearity to

584 detect RNA markers. All tests are four experimental replicas (two-tailed student's test; * $\mathrm{P}<$

$0.05, * * \mathrm{P}<0.01, * * * \mathrm{P}<0.001, * * * * \mathrm{P}<0.0001$; bars represent mean \pm s.d). 
medRxiv preprint doi: https://doi.org/10.1101/2020.03.05.20031971; this version posted March 12, 2020. The copyright holder for this preprint (which was not certified by peer review) is the author/funder, who has granted medRxiv a license to display the preprint in All rights reserved. No reuse allowed without permission.

Fig. 5

a Live cell detection

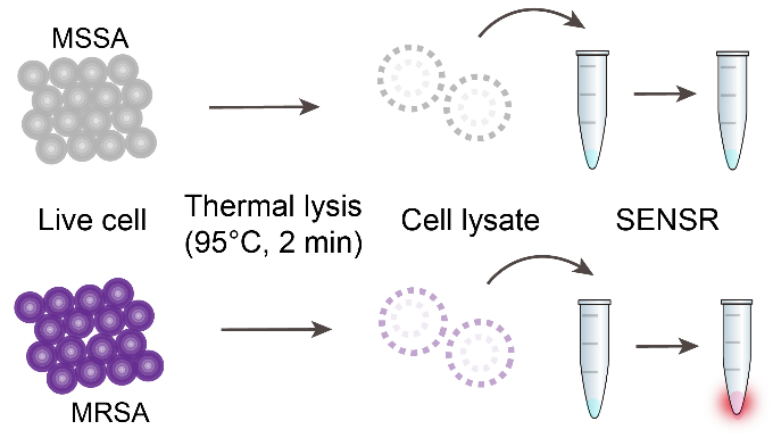

C Proxy clinical sample detection

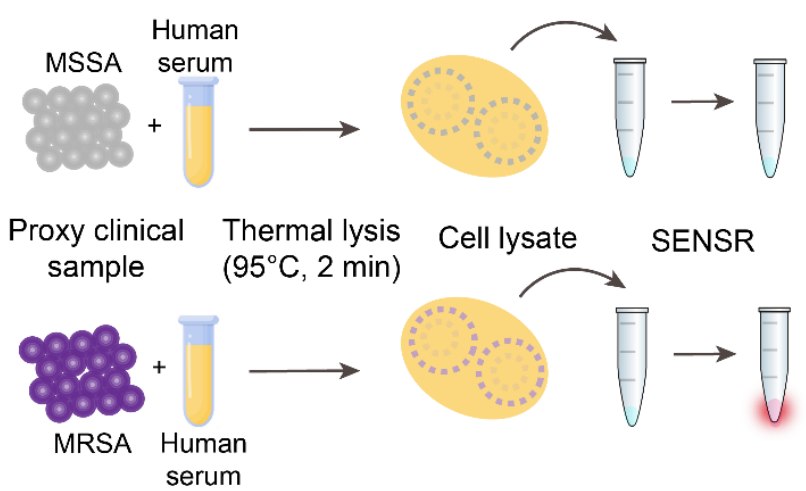

b

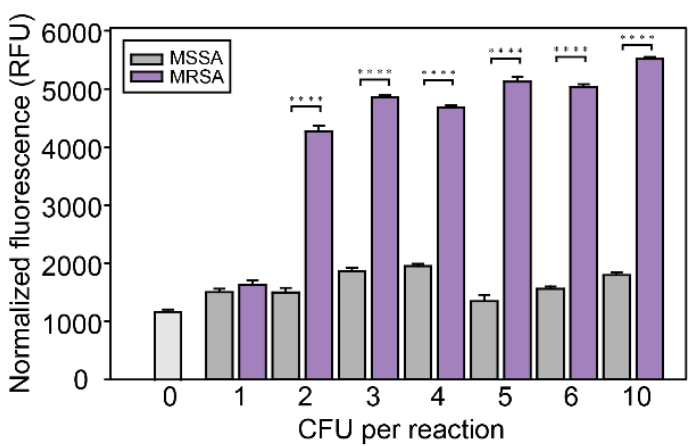

d

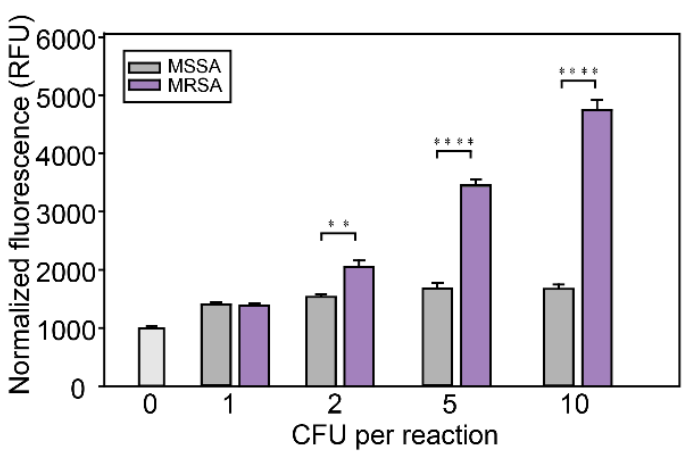

Fig. 5: Live cell and proxy clinical sample detection using SENSR. a, Direct detection of

589 bacterial cells. Thermal cell lysates of MRSA and MSSA were subjected to the SENSR

590 reaction. b, Clear distinction in the fluorescence intensity between MRSA and MSSA

591 samples. The detection limit of SENSR is as low as 2 CFU per $100 \mu \mathrm{L}$ reaction. c, Detection

592 of bacterial cell diluted in human serum as a proxy clinical sample. Bacteria-contained human

593 serum was thermally lysed and subjected to the SENSR reaction. d, An obvious distinction in

594 the fluorescence intensity between MRSA- and MSSA-contained human serum was

595 observed. The detection limit of SENSR is as low as 2 CFU per $100 \mu \mathrm{L}$ reaction. All tests are

596 four experimental replicas (two-tailed student's test; * $\mathrm{P}<0.05$, ** $\mathrm{P}<0.01$, *** $\mathrm{P}<0.001$,

$597 * * * * \mathrm{P}<0.0001$; bars represent mean \pm s.d). 
medRxiv preprint doi: https://doi.org/10.1101/2020.03.05.20031971; this version posted March 12, 2020. The copyright holder for this preprint (which was not certified by peer review) is the author/funder, who has granted medRxiv a license to display the preprint in All rights reserved. No reuse allowed without permission.

a

C

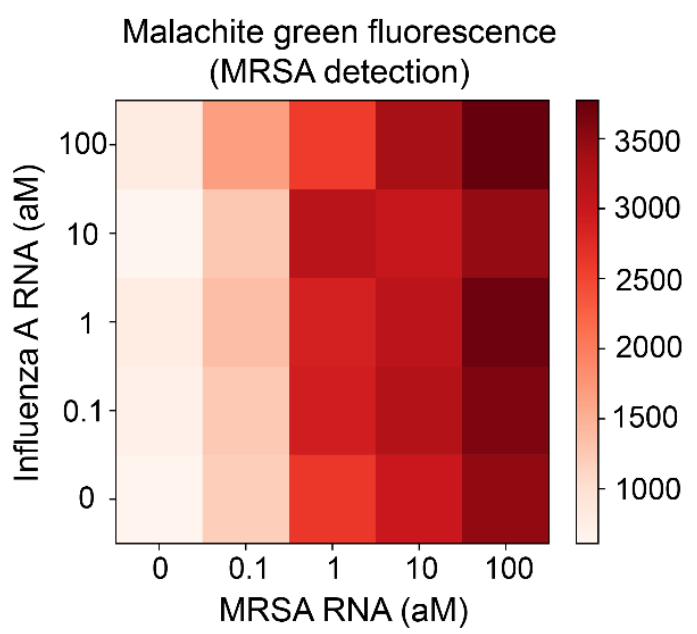

b

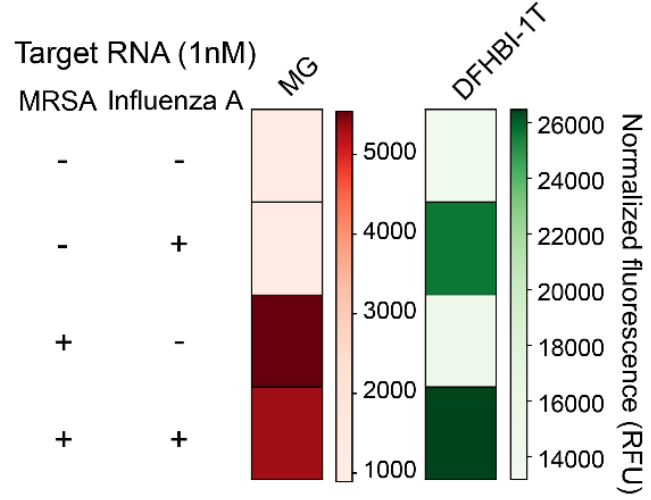

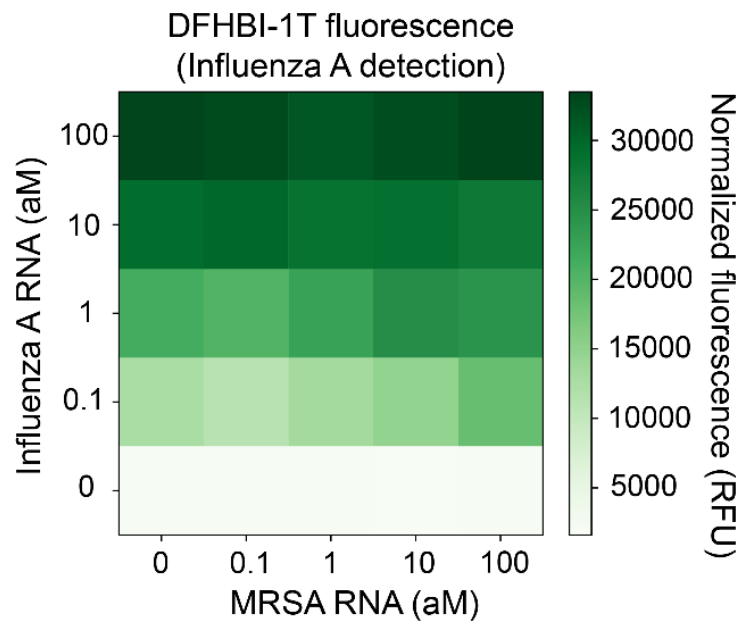

600 Fig. 6: One-pot dual detection of RNAs by SENSR. a, One-pot dual detection of MRSA

601 and Influenza A. The dual SENSR mixture contains two orthogonal pairs of probes and

602 fluorogenic dyes with other components. Each probe pair hybridizes to the corresponding

603 target RNA and allows SENSR reaction, emitting fluorescence that is distinguishable from

604 each other. b, Validation of orthogonal dual SENSR reaction. Presence of each target RNA (1

$605 \mathrm{nM}$ ) was determined by the intensities of non-overlapping fluorescence. c, One-pot dual

606 SENSR detection of MRSA and Influenza A with various concentration combinations. All

607 tests are four experimental replicas. 
medRxiv preprint doi: https://doi.org/10.1101/2020.03.05.20031971; this version posted March 12, 2020. The copyright holder for this preprint (which was not certified by peer review) is the author/funder, who has granted medRxiv a license to display the preprint in perpetuity.

All rights reserved. No reuse allowed without permission.

608

Fig. 7

a

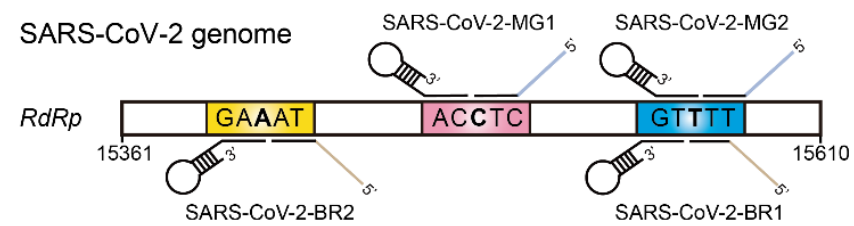

SARS-COV-2 ...GTGAAATGGTCA...AAACCTCATCA $\cdots$ GTGTTTTTAAC SARS-COV ...GTGAGATGGTCA...AAACATCATCC...GTGTCTTTAAC Bat-SARS 1 ...GTGAAATGGTTA...ATACATCTTCA $\cdots$ GTGTCTTTAAC Bat-SARS $2 \cdots$...GTGAGATGGTCA $\cdots$ AAACATCATCC $\cdots$ GTGTGTTTAAC

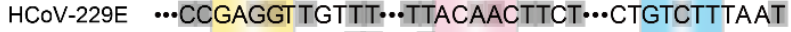
HCOV-NL63 ...CAGAAGTTGTTT...ATACGACTTCT...CTATTTTTAAC HCoV-OC43 ...CAGAAGTTGTTT...ATACGACTTCT...CTATTTTTAAC HCoV-HKU1 $\cdots$...GTGAAATTGTTA...TCACTAGTAGT...CAGTCTTTAAC

b

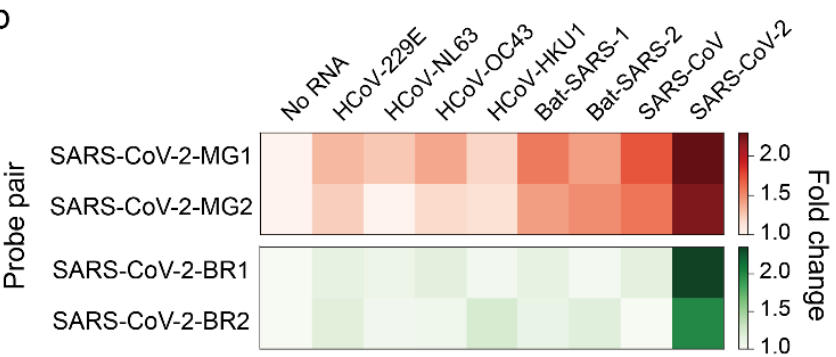

C

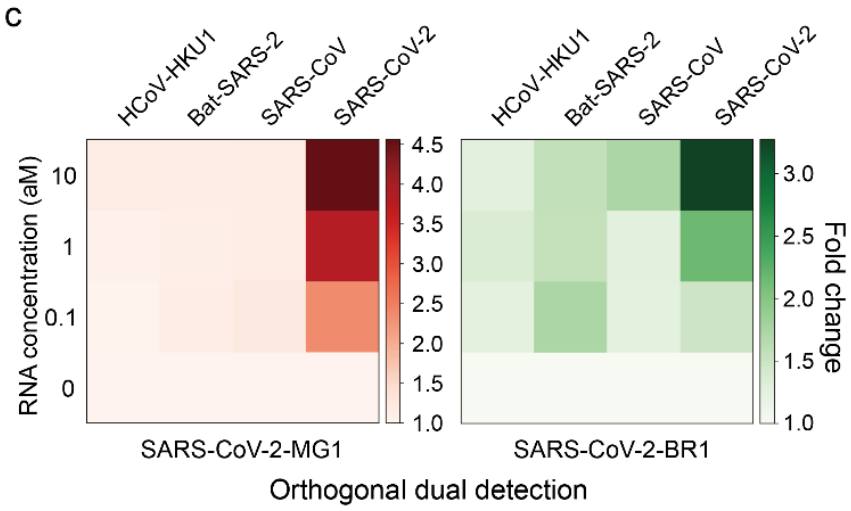

610 Fig. 7: Dual detection of SARS-CoV-2 by SENSR. a, Probe design for dual SENSR

611 detection. Three regions in the RNA-dependent RNA polymerase ( $R d R p)$ gene of SARS-

612 CoV-2 were targeted. Discriminatory bases that enable specific detection of SARS-CoV-2

613 against viruses with highly similar sequences are marked by bold letters. Grey shades indicate

614 mismatches between the sequences of SARS-CoV-2 and other viruses. b, Singleplex

615 detection of 1 aM SARS-CoV-2 RNA by SENSR. 229E, Human coronavirus 229E; NL63,

616 Human coronavirus NL63; OC43, Human coronavirus OC43; HKU1, Human coronavirus

617 HKU1; Bat-SARS-1, Mg772933 Bat SARS-related coronavirus; Bat-SARS-2, NC_014470 
medRxiv preprint doi: https://doi.org/10.1101/2020.03.05.20031971; this version posted March 12, 2020. The copyright holder for this preprint (which was not certified by peer review) is the author/funder, who has granted medRxiv a license to display the preprint in All rights reserved. No reuse allowed without permission.

618 Bat SARS-related coronavirus; SARS-CoV, Severe acute respiratory syndrome-related

619 coronavirus; SARS-CoV-2, Severe acute respiratory syndrome-related coronavirus 2. c,

620 One-pot dual detection of SARS-CoV-2 by orthogonal probe pairs, SARS-CoV-2-MG1 and -

621 BR1. All tests are two experimental replicas. Fold changes were calculated by dividing the 622 normalized fluorescence values by that with no target RNA. 